\title{
Research on the Elimination of the Foam of Leachate in Recycled Landfill
}

\author{
Lifang Guo \\ Department of civil engineering, Luoyang Institute of Science and Technology, China \\ E-mail: guolf222@163.com
}

Received: October 17, 2011

Accepted: November 14, $2011 \quad$ Published: December 1, 2011

doi:10.5539/jsd.v4n6p225

URL: http://dx.doi.org/10.5539/jsd.v4n6p225

\begin{abstract}
As we know, the quality and quantity of leachate change greatly, and organic ingredients are complex; It is difficult to resolve the foaming problem using biochemical method; And the cost of simple physical and chemical method is too high. The experiment find that we can easily eliminate chemical foam and dispose of most COD with little money by recycling the leachate to the landfill. The mothed not only reduces COD of the leachate but also accelerates rubbish in the landfill degradation.
\end{abstract}

Keywords: Form, Landfill, Leachate recycled to the landfill

\section{Introduction}

The organic content in leachate is high and their components are complex. If they enter into water body or soil, they will cause serious pollution and jeopardize human physical and psychological health(Wei Xu et al., 2011). The differences of components of refuse and landfill method can influence the property of leachate, which causes certain difficulty in follow-up harmless treatment of refuse. Using the method of biochemical process will produce a great deal of foam in the process(Jiang Shaohong, 2006), not conductive to the normal operation of the system; using the method of physiochemical process has large energy consumption and high cost, which is often used after biochemical process generally(Wan Yanlei, 2011). Through different characteristics shown by the leachate collected from different landfill structures of refuse, especial for the problem of foam appearance and disappearance in the process of recycling leachate to landfill, the experiment does the research and reveals the properties of leachate in different structures of landfills, and thus provides evidence for follow-up treatment to find out the treatment method with low cost and good effects.

\section{Experimental method}

The experiment takes a refuse column of semi-aerobic landfill and anaerobic landfill (as shown in figure 1) as research object. The landfill materials are domestic refuse collected from garage clearing station. In order to make the refuse column biological system start faster, 35 percent of aged refuse (which has been mineralized to soil) is mixed. In the process of recycling anaerobic and semi-aerobic refuse to the landfill, it is found that, for different structures of landfills, leachate shows different characteristics in the aspect of color, organic content, odor and whether there is form.

\section{Color and state}

Whether it is semi-aerobic landfill or anaerobic landfill, the changes of the colors of leachate experiences the process of yellow-black-yellow basically. For the leachate recycled to semi-aerobic landfill, it will change into inky black within half of a month, and mixed liquor contains a great deal of fine suspended matter. If stir, there will be foams with a little odor but not so pungent. The state will sustain about four months; then suspended matter and foam disappear gradually. Mixed liquor begins to become clear and the color changes from brown to orange yellow gradually; For the leachate produced by anaerobic structure landfill, it will remains yellow green for three months; it seems to be ropy gel solution with uniform properties and without suspended matters. It seems not dirty at a distance, but there is stench (which may contain a great deal of gases such as $\mathrm{H}_{2} \mathrm{~S}$ ). After three months and a half, the leachate gradually changes to black; after another half of a month, if stir, there will be a little foam and a small amount of suspended matters; only after over two months, it will change to orange foam and disappear gradually. 


\section{Micro-organisms}

From figure 2 it can be seen that, for semi-aerobic landfill column, the amount of aerobic micro-organisms have not made great changes between 50 days and 120 days as well as after 120 days, and anaerobic bacteria reduce a bit; but for anaerobic landfill column, between 135 days and 210 days, whether it is anaerobic bacteria or aerobic bacteria, their amount is less than that before 135 days but more than that after 210 days. The leachate produced by semi-aerobic landfill column will appear foam phenomenon when the number of total bacteria is large. And for the leachate produced by anaerobic landfill column, there will be foams when the number of total bacteria is relatively small. From the analysis above, it can be seen that there is no correlation between the amount of micro-organisms and the time period that foam produces. In the micro-organism plate experiment, it is also observed that the types of micro-organisms have not made any changes from in total process. Only the amount of different types has changed. Whether it is semi-aerobic landfill or anaerobic landfill, before the 120 days, the proportion of small plots with wet and smooth surface is high. After 180 days, the proportion of bacterial colonies with various states such as co-centre circles with dry and draped surface and bright color, white fluffy, black, like lotus leaf and so on increases, which means the number of bacteria is reducing relatively and the proportion of mould and actinomycetes in the amount of micro-organisms is increasing gradually. It is thought that the production of foam and the types of micro-organisms has no necessary relationship, which means that the possibility of biological foaming is very little.

\section{COD concentration}

From the experimental curve it can be seen that, for the leachate produced by semi-aerobic landfill column, between 30 days and 120 days, COD concentration drops rapidly; for anaerobic landfill column, during the period of from 135 days to 200 days, COD concentration descends suddenly; the two time periods is consistent with the time period that foam produces, and it can be seen that there is direct relationship between organic content and the production of foam. But when COD concentration is less than $10000 \mathrm{mg} / \mathrm{L}$, the leachate produced by semi-aerobic landfill column does not produce foam any more, but when COD concentration is less than $4000 \mathrm{mg} / \mathrm{L}$, the leachate produced by anaerobic landfill column does not produce foam. The properties of the components of anaerobic and semi-aerobic landfill column are different(Zhang wei \& Yue bo, 2010), which means that the components of organic matter in the leachate play decisive role in the production of foam. From the figure 3, we also can seen that after 270 days recycling to the landfill, the COD concentration of the leachate in semi-aerobic landfill may fall to $1100 \mathrm{mg} / \mathrm{L}$ and anaerobic landfill may also degrade to $2500 \mathrm{mg} / \mathrm{L}$.

The components of organic matters in the leachate can be divided into three types and they are low-molecular-weight fatty acid, intermediate-molecular-weight fulvic acid and humic high-molecular-weight carbohydrate respectively. But because the differences of the structures of landfills for semi-aerobic and anaerobic landfills make the amounts that the oxygen gas is obtained in the landfill are different, the properties of the leachate are also different. Through the analysis above we know that when COD concentration is less than $10000 \mathrm{mg} / \mathrm{L}$, the leachate produced by semi-aerobic landfill column does not produce foam any more, but the leachate produced by anaerobic landfill column does not produce foam when COD concentration is less than $4000 \mathrm{mg} / \mathrm{L}$, which shows that the organic content that can produce foam in the leachate produced by anaerobic landfill is far more higher that of semi-aerobic landfill. But the high-molecular-weight and intermediate-molecular-weight organic matters such as humates which exist in the solution makes the interfacial tension of the solution reduce, which is one of the important reasons for producing foam. From the comparison of the color and state of the leachate we find that, whether it is semi-aerobic landfill or anaerobic landfill, when their leachate becomes black and has suspended matters, COD degradation is rapid and there is foam phenomenon, but with the color of effluent leachate changing to yellow, the suspended matters and foam in the leachate also disappear. Expect for dissolvable organic matters, both suspended sludge and colloidal matters are important factors of forming stable foams(Lu Ning et al., 2007).

\section{Conclusions}

1) Whether is semi-aerobic landfill or anaerobic landfill, the color of the leachate recycled to the landfill experiences the process of yellow-black-yellow.

2) Foam produces along with COD rapid degradation, and the leachate is black and contains suspended matters.

3) The main reason for foams in the leachate is chemical foams.

4) The method of recycling the leachate to the landfill may reduce effluent COD value of the leachate in the landfill. The COD concentration of the leathate after disposal of the method is very low, which can adopt the method of physiochemical treatment directly to avoid the problem that it is difficult to eliminate the foam using 
biochemical treatment and save the cost of treatment.

\section{References}

Wei Xu, Xian Ping, Feng Qingge \& Zheng Shuangjin. (2011). Study on chracteristics of landfill leachate and its variations. Journal of Guangxi University. 3.

Jiang Shaohong. (2006). Research on Treatment of Landfill Lcachate with High Salinity Using a Combined Biofilm Process of AF-MBBR and Specific Halotolerant Bacteria. Tianjin University. 7.

Lu Ning, Zhou Jian \& He Qiang. (2007). Research on the Mechanism and Control of Foaming for high-concentration Sewage Treatment Plant. China Water and Wastewater. 1.

Zhang wei \& Yue bo. (2010). Stabilization Properties of Aged-refuse in Semi-aerobic and Anaerobic Landfills. Journal of Civil,Architectural \& Environmental Engineering. 14.

Wan, Yanlei. (2011). Research on treatment of landfill and its lcachate using physicochemical and biological process. Chongqing University. 3.

Table 1. The changes of color and state of leachate

\begin{tabular}{|c|c|c|}
\hline Name & semi-aerobic landfill column & aerobic landfill column \\
\hline $\begin{array}{c}\text { Half of a } \\
\text { month }\end{array}$ & Orange red & Orange yellow \\
\hline One month & The color deepens to black green & Orange yellow green \\
\hline $\begin{array}{c}\text { One and a } \\
\text { half months }\end{array}$ & inky black, have form & Orange yellow \\
\hline Two months & inky black, have form & grassy yellow green \\
\hline 2.5 months & inky black, have form & Orange yellow \\
\hline 3 months & black, have form & dark red with a little green \\
\hline 3.5 months & black, have form & shallow black, turbid \\
\hline 4 months & black, have form & black, have foam, turbid \\
\hline 4.5 months & brown & inky black, have foam, turbid \\
\hline 5 months & orange yellow & orange yellow \\
\hline 5.5 months & inky black green & more inky black, have foam, turbid \\
\hline 6 months & reddish-brown with a little green & green black with a little of foam \\
\hline 6.5 months & red-yellow-green & orange reddish green \\
\hline 7 months & orange red & with a little green, have foam, turbid \\
\hline 9 months & oreen & with a little green, have foam, turbid \\
\hline
\end{tabular}




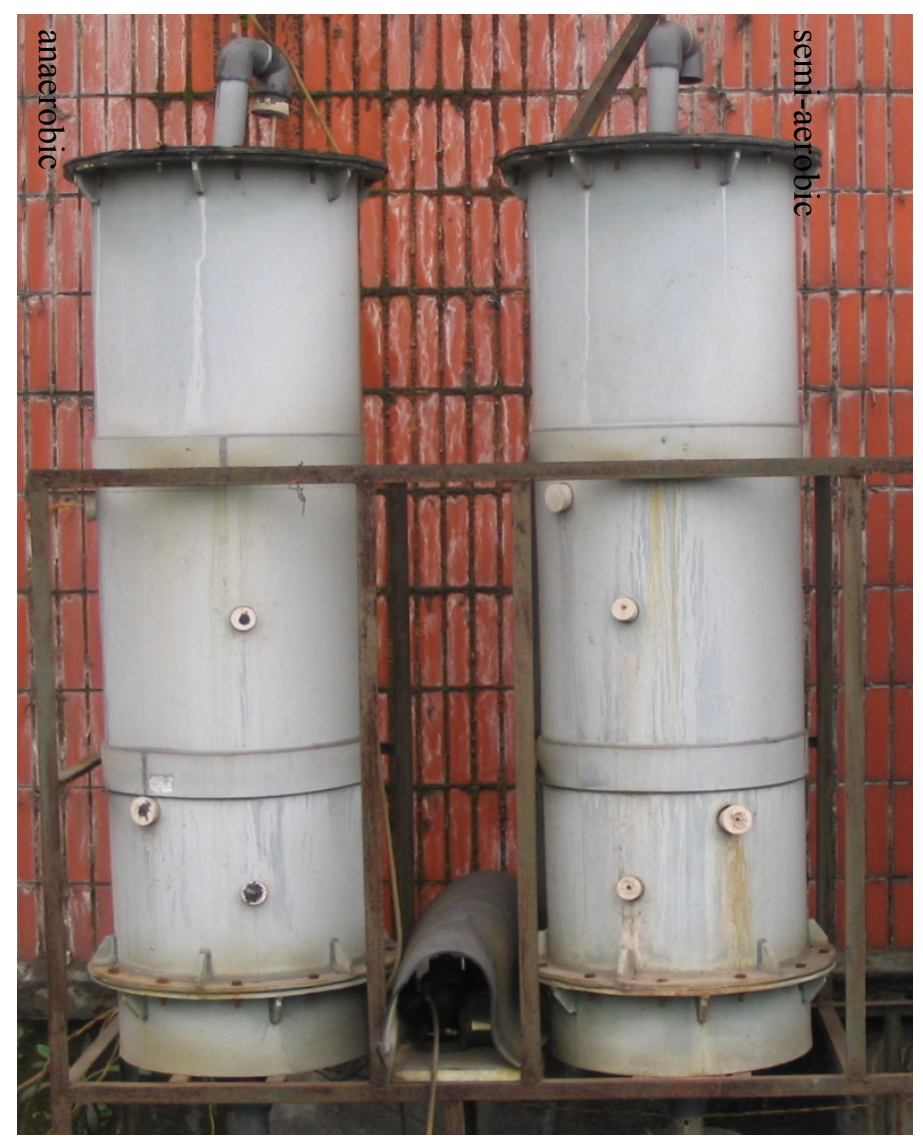

Figure 1. The refuse column of semi-aerobic landfill and anaerobic

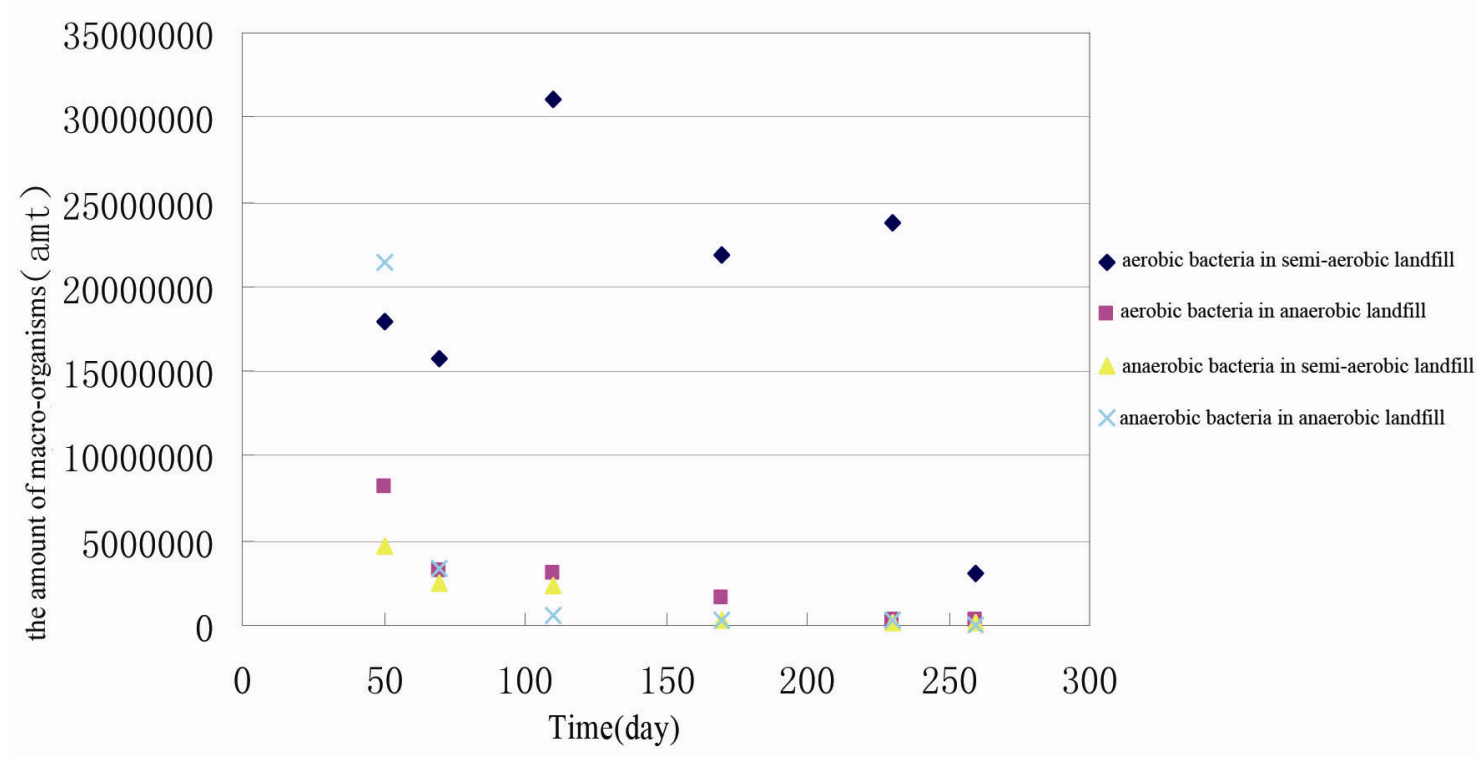

Figure 2. the changes curve of the amount of macro-organisms in semi-aerobic and anaerobic landfill column as time goes on 


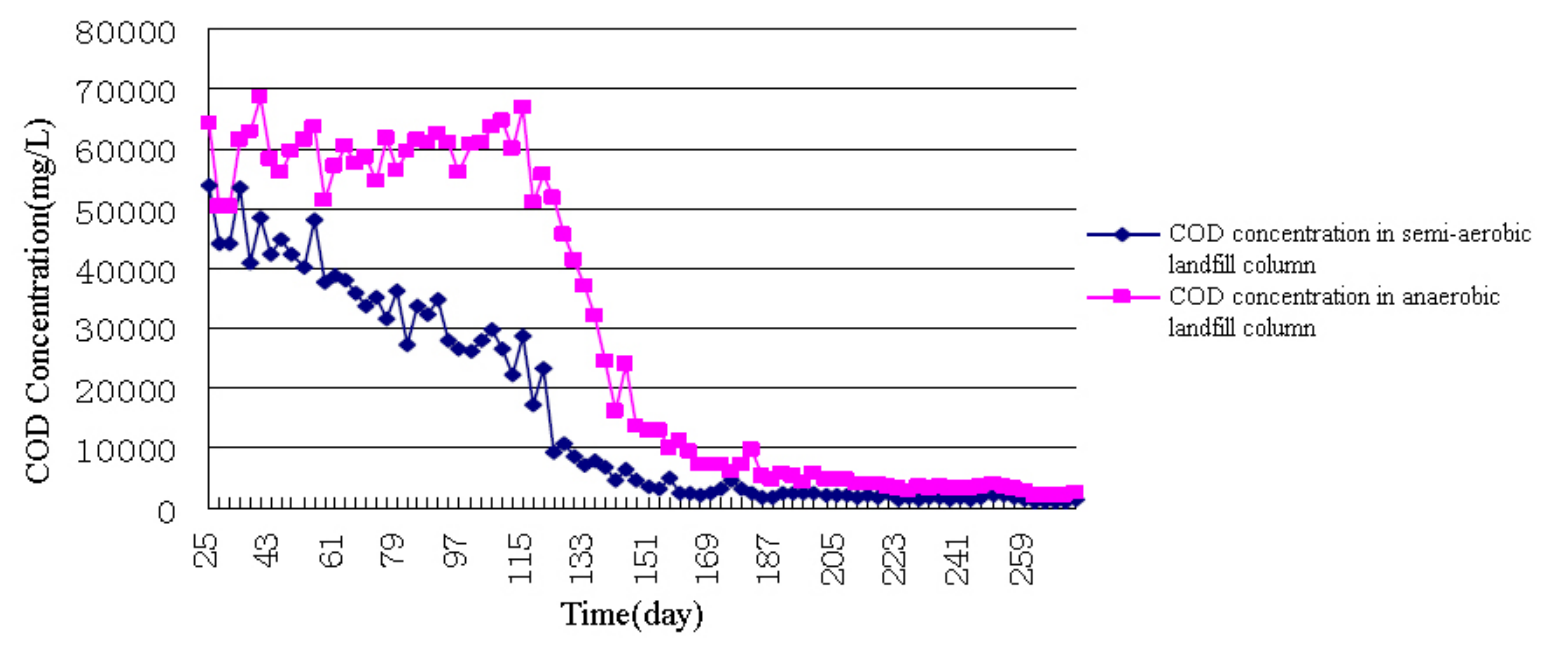

Figure 3. the change curve of COD concentration as time goes on 